\title{
Study on the Policy Guarantee for "Double-qualified" Teacher's Cultivation of Local Undergraduate Colleges and Universities
}

\author{
Shuxia Qian \\ Jilin Agricultural University \\ Jilin, China
}

\author{
Xiaoming Zhang \\ Jilin Agricultural University \\ Jilin, China
}

\begin{abstract}
With the constant and further transformation of higher education, the demands for "double-qualified" teachers are increasing to meet the requirements of applied talents cultivation, and the cultivation of "double-qualified" teachers becomes the key task to enhance educational quality of colleges and universities and achieve the objective of talents training, while this requires a guarantee in relevant policies and systems. This article explains the necessity of policies and systems for cultivating "double-qualified" teachers in local undergraduate colleges and universities and further puts forwards some applicable and reasonable policies and systems to guarantee the cultivation of "double-qualified" teachers.
\end{abstract}

Keywords-local undergraduate colleges and universities; double-qualified; teacher cultivation; policy guarantee

\section{INTRODUCTION}

In November 2015, the Ministry of Education along with other ministries printed and issued the Instructions for Guiding the Applied-Talent Transformation In Part of Local General Undergraduate Colleges, and since then each province launched pilot work on the transformation from general undergraduate colleges to applied talent centers; in case such transformation succeeds, colleges will shoulder the important mission of high-level applied-talent cultivation. Moreover, the key to this incredible mission, cultivating high-level applied talents, is to build a superior qualify team of "doublequalified" teachers. In other words, building a team of "double-qualified" teachers suitable for the development orientation of colleges and satisfying the requirements for realizing objective of talent cultivation, has become the primary task for the achievement of transformation development of local general undergraduate colleges [1]. However, at present researching on "double-qualified" teacher cultivation in general undergraduate colleges is at the primary stage, in particular, with rarely policy guarantee. This article explains the necessity of policies and systems for cultivating "double-qualified" teachers in local undergraduate colleges and universities and, on the basis of analyzing problems and difficulties in cultivating "double-qualified" teachers of those colleges, further come up with some applicable and reasonable policies and systems to guarantee the cultivation of "doublequalified" teachers.

\section{NeCESSITY OF ESTABLISHING POLICIES AND S YSTEMS ON “DOUBLE-QUALITY” TEACHERS IN LOCAL UNDERGRADUATE COLLEGES}

Teachers are the foundation of education. It is difficult and even impossible to realize the objective of talents training without high-level teachers. Local undergraduate colleges have put forward higher requirements no matter for all-round improvement of higher education quality, characteristic development, and connotative development or for transformation to practice. In spite of all those years went by since the team construction of "double-qualified" teachers in institutions of higher learning has been already raised, such fashioned "double-qualified" teacher teams are not common at all, not to mention a mature but rare "double-qualified" teacher cultivation system.

\section{A. Formulating Policies and Systems on "Double-qualified" Teacher Cultivation Is Necessary for College \\ Transformation}

The essence of transformation development of local colleges is rooted in the conversion of objective of talents training that is, from cultivating academic talents to plied and technical talents, and the objective of talents training for local undergraduate colleges, after a successful transformation, will correspondingly turn into cultivating high-quality and applied talents with both extensive theoretical knowledge and adequate practical ability, and that "double-qualified" teachers are just the key to cultivating those satisfactory talents. Ministry of Education has highlighted, in Instructions for Guiding the Applied-Talent Transformation In Part of Local General Undergraduate Colleges, to strengthen the construction of "double-qualified/ability" teaching staff, to intensify the combination of industry and major, to increase degree of coincidence between experiment, internship and practical training level and professional education as well as the occupancy and quality of double-qualified teachers, and to deepen the investigation and study on breadth and depth of university-enterprise cooperation etc. Despite of the fact that the cultivation of "double-qualified" teachers is necessary for colleges to fulfill transformation, it still requires favorable policies and systems as a guarantee and specification; otherwise the splendid blueprint is nothing but castle in the air. 


\section{B. Formulating Policies and Systems on "Double-qualified" Teacher Cultivation Is Necessary for the Effective Operation of "Double-qualified" Teacher Cultivating Mechanism}

A scientific and effective cultivation mechanism plays a vital and required role in training "double-qualified" teachers; at the same time policies are also requested to ensure the effective operation of the cultivation mechanism. So far the country has set forth a series of legislated files concerning the transformation of local undergraduate colleges; in particular some laws, regulations and policies [2] have been involved in the cultivation and team construction of "double-qualified" teachers. Nevertheless, the system guarantee for "doublequalified" teacher cultivating mechanism in local undergraduate colleges is far from sufficient and in dire need of establishment and perfection to eventually realize the effective operation of "double-qualified" teacher cultivating mechanism built by those colleges and cast off chaos due to no system guarantee once and for all.

\section{Formulating Policies and Systems on "Double-qualified" Teacher Cultivation Is Necessary for the Self-development of Teachers}

The transfer of educational focus on applied cultivation of local undergraduate colleges bring about challenges to teachers of research universities whose knowledge acquired during their school time under a traditional teaching outline and mode is no longer applicable for the further career, and absence of practical skills has turned out to be a short slab of teaching that can only be overcome by relocating their career planning, attaching importance to self-development and conscientiously fostering the quality of a "double-qualified" teacher. And yet, self-development of teachers can never be fulfilled without a suitable institutional framework, so scientific and reasonable systems and policies are a guarantee to improve the selfdevelopment of teachers.

\section{Problems ANd Difficulties IN “Double- QUALIFIED” TEACHER CULTIVATING}

Considering that the "double-qualified" teacher cultivation in undergraduate colleges is a new subject come up in recent years, and has never been taken seriously before the applied transformation of local general undergraduate colleges; besides, comparing to vocational and technical colleges, such a "novelty" has been confronted with numerous problems and dilemmas but under much less corresponding policy guidance and system restrictions.

\section{A. Not Thorough Understanding on "Double-qualified" \\ Teachers and Absence of Policy Guidance}

After the successful applied transformation of local undergraduate colleges, in allusion to the demands of applied talents for "double-qualified" teachers, those colleges should have attached attention to the cultivation of "double-qualified" teachers; but in reality, a large part of general undergraduate colleges fail to deeply understand the transformation concept resulting in superficial cognition and insufficient value on "double-qualified" teachers [3] in addition to lack of policy guidance stipulated by administrative departments of education, all of which drags the development of "double-qualified" teacher cultivation behind.

\section{B. Ill-Defined "Double-qualified" Teachers of Undergraduate Colleges, Lack of Scientific Demarcation and Identification Standard}

Is there any difference between the "double-qualified" teachers of local undergraduate colleges and the "doubleability" teachers emerging in the process of vocational and technical education? What kind of should the "doublequalified" teachers of local undergraduate colleges be? How to define a "double-ability" teacher? All those questions remain unsolved, and so far there is neither scientific demarcation nor identification standard on the "double-ability" teachers.

\section{Absence of Guarantee System for "Double-qualified" \\ Teachers, Incomplete and Unsound System}

Cultivating "double-qualified" teachers requires applicable policies and systems as a guarantee to the realization and implementation of cultivating mechanism for fear of becoming a mere formality. At this stage not only no relevant laws or regulations have been formulated to standardize the "doublequalified" cultivation in local general undergraduate colleges, but the "double-qualified" cultivating mechanism of most colleges have not been completed yet, leaving a great gap in corresponding evaluation and stimulation mechanisms; in addition, some of them cannot perfectly fit in with the demands for cultivating "double-qualified" teachers in local undergraduate colleges, all of which makes it hard to realize construction objective of "double-qualified" teaching staff.

\section{ENACTMENT AND PERFECTION OF POLICIES AND SYSTEMS ON “DOUBLE-QUALIFIED” TEACHER Cultivating}

The establishment of policies and systems is an important link of cultivating "double-qualified" teaching staff in local general undergraduate colleges. An excellent "doublequalified" teaching team is never accomplished in an action, but requires a certain suitable policies and systems that make the successful cultivation of "double-qualified" teachers possible.

\section{A. Lay Down the System and Standard on "Double- qualified" Teaching Qualification Certification, Perfect the "Double-qualified" Teacher Cultivating Mechanism}

So far an applicable uniform and acknowledged standard on "double-qualified" teaching qualification certification has never been formulated, except for the current indiscriminately imitated standards from some vocational colleges that utterly vary to schools. Therefore, the administrative departments of higher education are required to, according to characteristics of "double-qualified" teachers in undergraduate colleges and differences from vocational colleges, set out certification systems and approval standards suitable for targeted colleges to ensure the smooth implementation of teaching certification work related to "double-qualified" teachers of undergraduate colleges. Meanwhile, it is necessary for local undergraduate colleges to establish an effective "double-qualified" teacher 
cultivating mechanism to guide teachers to positively participate in the certification of "double-qualified" qualification and to provide supports and services for the cultivation of "double-qualified" teachers in addition to encouraging the "double-qualified" development of teachers.

\section{B. Formulate Recruitment and Employment System of "Double-qualified" Teachers, Guide Teachers to Attend Various Tests of Skill Evaluation}

In accordance with the requirements of "adjust teachers' structure, reform the teacher employment system and assessment methods, positively bring in universally acknowledged talents among the industry, employ excellent professional and technician talents, management talents and high-skilled talents from enterprises to be the leader of professional building and act as full-time/part-time teachers" as quoted from Instructions for Guiding the Applied-Talent Transformation In Part of Local General Undergraduate Colleges, local undergraduate colleges should continue to construct and reform "double-qualified" teacher employment system and lift the control over recruitment conditions within certain limits; besides, they should initiate the mutual employment of teachers in universities and colleges and technicians in enterprises and public institutions and encourage teachers to hold "double-qualified positions"; at the same time, hiring some part-time teachers from enterprises and public institutions can compensate for the deficiency of "doublequalified" teaching teams; on the other hand, teachers in universities and colleges can acquire part-time jobs in enterprises and public institutions to gain required ability of a "double-qualified" teachers by practice [4]. Moreover, it requires drawing up an evaluation system on professional teaching skills and guiding professional teachers to initiatively attend various skills identification tests so as to improve the trainings on the practical ability of "double-qualified" teachers.

\section{Complete the "Double-qualified" Teaching Quality \\ Assessment System, Particular Lay Emphasis on Practical Skill Assessment}

The cultivation of "double-qualified" teachers in the local undergraduate colleges and universities not only needs to improve the "double-qualified" teacher cultivating mechanism, but requires an assessment system conducive to the development of "double-qualified" teachers and growth, in addition to setting up the evaluation index system different from other index system of teachers, instead of the original evaluation system, to focus on the examination and assessment of professional and technical ability of practice of teachers, and meanwhile fade out the standards of academic research of teachers, as well as to promote the better and faster development of "double-qualified" teachers through the reform of evaluation systems and standards.

\section{Enact and Complete "Double-qualified" Teacher \\ Incentive System; Improve Treatment of "Double- qualified" Teachers}

It is necessary to clear the status of "double-qualified" teachers and improve the "double-qualified" teacher incentive system; besides, it should adopt the mode of combining the material rewards and spiritual encouragement and set out incentive policies concerning employment conditions and wages appropriately distinct with other teachers. With regard of the professional evaluation and promotion, selection and awarding, abroad education and academic funding etc. of the "double-qualified" teachers, it requires developing appropriate care and preferential policies to fulfill the spiritual encouragement and making full advantages of the important role of evaluation incentive mechanism [5].

\section{E. Formulate the Related Policies on "Double-qualified" Teaching Development; Promote Lifelong Development of Teachers}

The practical ability of "double-qualified" teachers is not innate but the most is acquired through practice and training in enterprises; therefore, local colleges should pay attention to the teaching development and occupation career planning of teachers by formulating development policies to promote the development of "double-qualified" teaching and provide protection for the development of those teachers [6]. At the same time, it requires projects designed and developed suitable for the development of "double-qualified" teachers to encourage teachers to participate actively in trainings of teacher development projects and promote teachers' lifelong development.

Set out policies on developing practical teaching bases; fasten the construction of "double-qualified" teaching training bases

Local undergraduate colleges and universities should have a relatively perfect training base as the backing to the cultivation of the "double-qualified" teachers, and the establishment and perfection of practice base requires the related policy systems as a security; besides, local undergraduate colleges and universities should develop fund, equipment, personnel, security system for practice base and improve the existing conditions, to ensure to meet requirements of "double-qualified" teachers both in quantity and quality, in addition to promoting the rapid development of the practice base and providing guarantee for practical skills training of "double-qualified" teachers.

\section{CONCLUSION}

In conclusion, "double-qualified" teacher cultivation plays an indispensable role in the transformation of local undergraduate colleges, while the cultivation and construction of domestic "double-qualified" teacher teams are still confronted with lots of issues and challenges which require to be solved through corresponding policies and systems set out by concerned authorities to guarantee the cultivation of "double-qualified" teacher teams. Furthermore, all administrative departments of higher education and local undergraduate colleges should fully realize the significance of "double-qualified" teachers for cultivating applied talents, further reflect on and study the way to intensify the construction of "double-qualified" teaching staff in undergraduate colleges; besides, it should make formulation and perfection of "double-qualified" teacher cultivation system 
on the agenda and provide a reliable policy guarantee for the cultivation of "double-qualified" teachers.

\section{REFERENCES}

[1] Gai Qionghui, Lv Chaodian. Exploration on Construction of "Doublequalified" Teaching Staff in Local General Undergraduate Colleges[J]. Data of Culture and Education, 2016 (12): 111-113

[2] Wang Zhonghua. Plight and Outlet of Construction of "Doublequalified" Teaching Staff during the Transformation of Local General Undergraduate Colleges[J]. Journey of Nanchang Normal University (social sciences), 2016 (4): 41-45

[3] Guo Mingjie, Jiang Xiaoling. Discussion on Construction of "Doublequalified" Teaching Staff in Local Undergraduate Colleges[J]. Xueshu Baijia, 2016 (4): 62-64

[4] Li Na. Feature Analysis of Vocational Competency of "Doublequalified" Teachers in Undergraduate Colleges[J]. Journal of Qiqihar Junior Teachers' College, 2016 (1): 25-27

[5] Lu Xiaoyan. Exploration and Analysis of Construction of "Doublequalified" Teaching Staff during the Transformation of Local Undergraduate Colleges[J]. Journey of Chifeng University (JCR Science Edition), 2016 (5): 245-246

[6] Xiao Zhixiong, Qin Bei. Research on the Professional Development Management on "Double-qualified" Teachers[J]. Journal of Higher Education, 2016 (9): 227-228 